\title{
An Overview of Performance Evaluation of Sewage Treatment Plant
}

\author{
Ankit $^{1}$, S.K. Singh ${ }^{2}$ \\ 1,2 Environmental Engineering, Delhi Technological University, Delhi, India
}

\begin{abstract}
Sewage whether treated or untreated, ultimately discharge in lakes, rivers, streams, and oceans. We consider groundwater as pure, but unfortunately, sewage is one of the major reason behind wastewater associated diseases. Nearly $78 \%$ of the water flows back to the environment without any treatment. This can lead to a numerous health and environmental problems so it is better to treat wastewater before disposal and further proper management can help in meeting the public's water demand. As per today's scenario, number of innovations are required to operate treatment plant at high efficiency because of increasing domestic, commercial, and industrial waste. And this rise is taking place due to several reasons - urbanization, increasing population, economic development, and improved living conditions etc. Nowadays people of both urban and peri-urban areas are using waste water to irrigate their crops, often because they do not have any alternate source of irrigation water. New technologies are continuously being introduced in sewage treatment plant to exhibit good performance. The paper focuses on reviewing the various sewage treatment methods and their results.
\end{abstract}

Keywords - STP, Wastewater, Removal Efficiency, Characteristics

\section{Introduction}

Water is the most significant resource in the world, and now is in danger due to urbanization, increasing population, inadequate rainfall, climatic change, and economic development etc. Water is required to be used efficiently due to its increasing demand [1]. This can be achieved by using existing sources of water with proper management and adopting both traditional and modern approach for improving efficiency such as ground water recharge, conservation of water, and reuse of waste water etc. Among all the methods, reuse of waste water has become the most important for both economic and environment reasons. Earlier wastewater after treatment was used in agricultural activities but nowadays it is intensifying its applications in urban, industrial and construction industry. The important pathways for reuse of waste water contains surface water replenishment, irrigation, ground water recharge, and industrial use [2]. The volume of water carried through each pathway depends on degree of water utilized for different purpose, climatic factors, watershed characteristics, quantity of direct and indirect water reuse. Also water problems are in need of immediate assistance because of increasing environmental hazards to human health.

\subsection{Sewage Treatment Plant}

Sewage is the waste produced from institutional, industrial, residential, and commercial establishments. Sewage treatment involves number of stages for eliminating the contaminants from household or industrial sewage water [3]. Sewage treatment plant treats the waste water/sewage before its disposal into the water body so that it can be used in domestic or 
agricultural activities safely. Sewage consists of high quantity of inorganic and organic wastes. It becomes very important to treat sewage appropriately before letting into any source of water.

\subsection{Working of Sewage Treatment Plant}

Sewage treatment involves several stages in treatment process and is mentioned below:

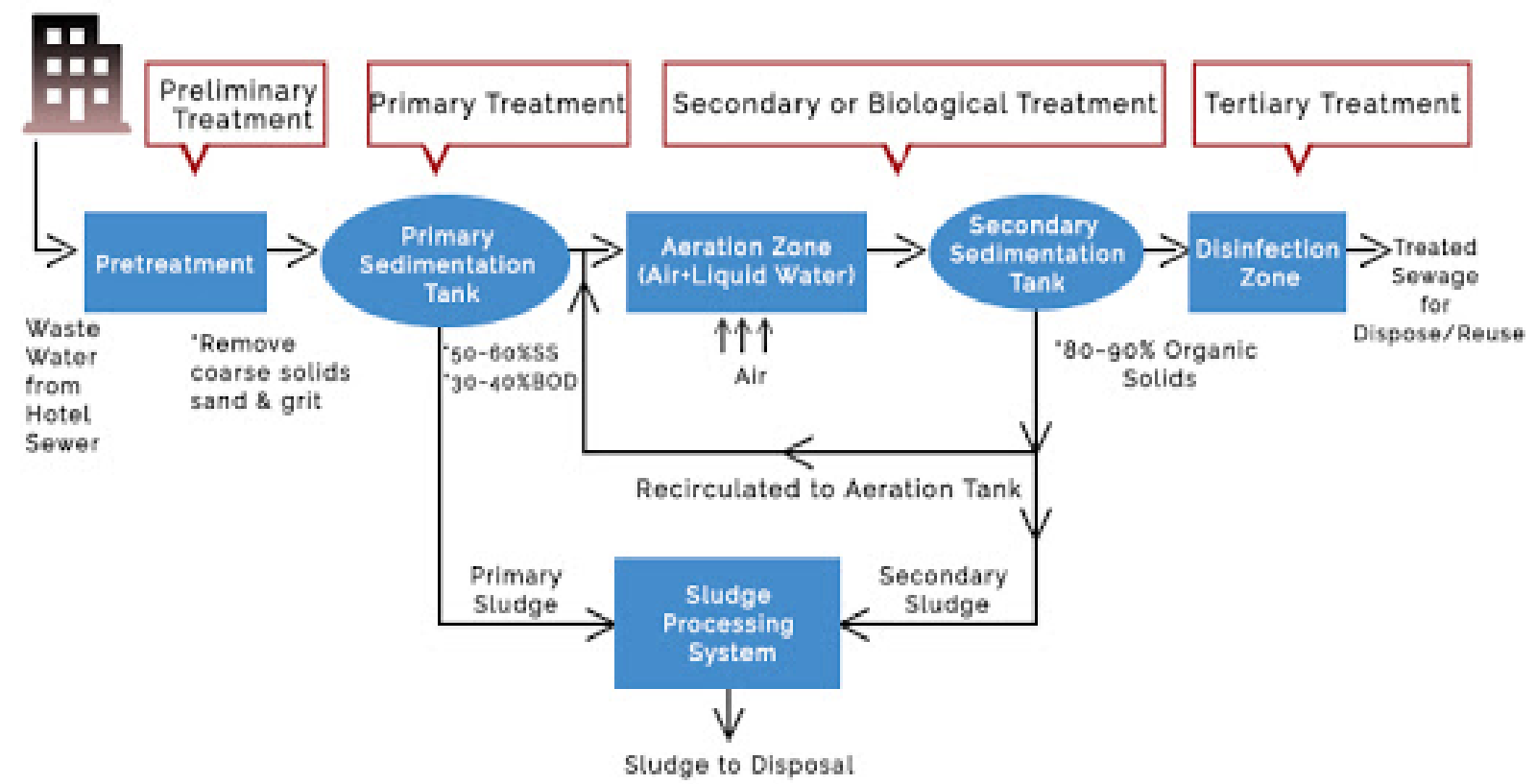

> Preliminary Treatment: This is the initial stage/ first stage of wastewater treatment which includes removal of large materials or coarse solids usually found in raw water. This treatment consists of filtering screen which helps in breaking the large objects to prevent blockage in treatment process. Preliminary treatment stage also includes flow measurement devices.

$>$ Primary Treatment: This treatment takes place after preliminary treatment which aims to reduce any kind of heavy solids that are settled at the bottom due to sedimentation while light solids like oil and grease float over the surface by skimming [3]. After removing the both floating and settled materials the remaining liquid is discharged to next stage of treatment. The efficiency of primary treatment is to remove around $60 \%$ of suspended solids from sewage.

> Secondary Treatment: This treatment takes place after removal of floating and settled materials from the sewage which aims at removing suspended and dissolved biological matter. Secondary sludge which is removed during secondary sedimentation is generally mixed with primary sludge for sludge processing. This treatment involves a separation process for removal of microorganisms from treated water before moving to next stage of treatment. The efficiency of secondary treatment is to remove around $90 \%$ of suspended solids from sewage.

$>$ Tertiary/Advanced Treatment: This treatment takes place after secondary treatment and aims at removing those sewage constituents which were not removed in prior 
stages. Sometimes treated sewage is disinfected physically or chemically before its discharge into the ecosystem (river, sea, wet lands, lake, ground, etc.

\section{LEVEL OF TREATMENT REQUIRED FOR DIFFERENT PURPOSES}

\begin{tabular}{|l|l|l|}
\hline $\begin{array}{l}\text { Sr. } \\
\text { No. }\end{array}$ & Purpose/Use & Level of Treatment \\
\hline 1 & Direct use & Sixth level treatment with RO \\
\hline 2 & Indirect potable use & Fifth level treatment \\
\hline 3 & Industrial non potable use & Fourth level treatment \\
\hline 4 & Restricted Urban use & Tertiary treatment \\
\hline 5 & Irrigation & Secondary treatment \\
\hline
\end{tabular}

\section{Literature Review based on variation of different parameters in Sewage Treatment Plant}

\subsection{Dissolved Oxygen and Biochemical Oxygen Demand}

Hassan et al. (2015) conducted study on BOD, COD, and DO of sewage treatment plant, which recorded $7.78 \mathrm{mg} / \mathrm{l}$ at receiving point and $7.82 \mathrm{mg} / \mathrm{l}$ at outlet [4]. The research on water quality assessment of sewage treatment plant is conducted by Agyemang et al. (2013) which gave $3.6 \pm 0.6 \mathrm{mg} / \mathrm{l} \mathrm{DO}$ at receiving point and $5.7 \pm 0.6 \mathrm{mg} / \mathrm{l} \mathrm{DO}$ at outlet [5]. Bhagwatkar et al. (2017) conducted a study of decentralized sewage treatment which stated DO at receiving point is lower than detection limit and greater than $2 \mathrm{mg} / \mathrm{l}$ at outlet [6]. Also a Bhaarat et al. conducted a study on wastewater of pharmaceutical industry which resulted in $1.4 \mathrm{mg} / \mathrm{l} \mathrm{DO}$ at receiving point and $4.5 \mathrm{mg} / \mathrm{l}$ at outlet [7].

Rajkumar (2016) performed a study on interpretation of biological method for the sewage treatment and found $225 \mathrm{mg} / \mathrm{l}$ BOD at receiving point and $9 \mathrm{mg} / \mathrm{l}$ at outlet [8]. A study on water quality assessment of sewage treatment plant was conducted by Agyemang et al. (2013) which recorded $1118.6 \pm 182.5 \mathrm{mg} / \mathrm{l} \mathrm{BOD}$ at receiving point and $45.7 \pm 35.2 \mathrm{mg} / \mathrm{l}$ at outlet [5]. Patil et al. (2018) performed a study on design of sewage treatment plant units which stated BOD of $189.78 \mathrm{mg} / \mathrm{l}$ at receiving point and $30-150 \mathrm{mg} / \mathrm{l}$ at outlet [9]. The outcome of study conducted by Bhagwatkar et al. (2017) on decentralized sewage treatment reported 100-200 $\mathrm{mg} / \mathrm{l}$ at receiving point and less than $5 \mathrm{mg} / \mathrm{l}$ at outlet [6]. Dahamsheh and Wedyan (2017) performed a study on interpretation of performance of sewage treatment plant which recorded BOD of $335.7 \mathrm{mg} / \mathrm{l}$ at receiving point and $15.5 \mathrm{mg} / \mathrm{l}$ at outlet [10]. Sahu and Negi (2015) studied performance evaluation of waste water treatment plant which recorded BOD of $200.46 \mathrm{mg} / \mathrm{l}$ at receiving point and $22.6 \mathrm{mg} / \mathrm{l}$ at outlet [11].

\begin{tabular}{|c|c|c|c|c|}
\hline \multirow{2}{*}{ Author } & \multicolumn{2}{|c|}{ DO (mg/l) } & \multirow{2}{*}{ Remarks } & \multirow{2}{*}{ Ref. } \\
\hline & Inlet & Outlet & & \\
\hline $\begin{array}{l}\text { Agyemang et al. } \\
\text { (2013) }\end{array}$ & $3.6 \pm 0.6$ & $5.7 \pm 0.6$ & $21 \%$ increase in DO. & {$[5]$} \\
\hline $\begin{array}{l}\text { Bhagwatkar et al. } \\
\text { (2017) }\end{array}$ & BDL* & $>2$ & Dissolved Oxygen level improved & {$[6]$} \\
\hline Hasan et al. (2015) & 7.78 & 7.82 & Organic matter was oxidized. & {$[4]$} \\
\hline
\end{tabular}




\begin{tabular}{|l|l|l|l|l|}
\hline \multirow{2}{*}{ Bharat et al. (2013) } & \multicolumn{1}{|c|}{1.4} & \multicolumn{1}{|c|}{4.5} & Increased up to 5ppm level. & [7] \\
\hline Author & \multicolumn{2}{|c|}{ BOD (mg/l) } & Remarks & Ref. \\
\cline { 2 - 5 } & Inlet & Outlet & Agyemang et al. \\
(2013) & $1118 \pm 192$ & $45.7 \pm 35.2$ & $93 \%$ BOD Reduction. & {$[5]$} \\
\hline Patil et al. (2018) & 189.78 & $30-150$ & $\begin{array}{l}\text { Treatment contained solely in separating the } \\
\text { suspended materials. }\end{array}$ & {$[9]$} \\
\hline $\begin{array}{l}\text { Bhagwatkar et al. } \\
\text { (2017) }\end{array}$ & $100-200$ & $<5$ & Self-reliabale sanitation solution. & {$[6]$} \\
\hline $\begin{array}{l}\text { Sahu and Negi } \\
\text { (2015) }\end{array}$ & 200.46 & 22.6 & Post ultra-filters quality of treated water. & {$[11]$} \\
\hline \begin{tabular}{l} 
Rajkumar (2016) \\
\cline { 1 - 5 }
\end{tabular} & 225 & 9 & $\begin{array}{l}\text { Paper board industry sewage treatment } \\
\text { operation and removal performance. }\end{array}$ & {$[8]$} \\
\hline $\begin{array}{l}\text { Wahamsheh and } \\
\text { Wedyan (2017) }\end{array}$ & 335.7 & 15.5 & 93.7- 96.6 \% of BOD lowered & {$[10]$} \\
\hline
\end{tabular}

Review based on variation in DO and BOD in STP plant

\subsection{Conductivity and pH}

A study on water quality assessment of sewage treatment plant was conducted by Agyemang et al. (2013) which results in conductivity of $1748.6 \pm 20 \mu \mathrm{S} / \mathrm{cm}$ at receiving point and $840 \pm 48$ $\mu \mathrm{S} / \mathrm{cm}$ at outlet. Durga et al. (2013) performed the study on treatment efficiency of algae based waste water treatment plant which stated conductivity of $987 \mu \mathrm{S} / \mathrm{cm}$ at receiving point and $1080 \mu \mathrm{S} / \mathrm{cm}$ at outlet [12]. The outcome of study conducted by Khushwah et al. (2012) reported conductivity of $2.323 \mu \mathrm{S} / \mathrm{cm}$ at receiving point and $1.423 \mu \mathrm{S} / \mathrm{cm}$ at outlet [13]. And Khushwah et al. (2011) performed a study on seasonal variation of physiochemical parameters of sewage and found conductivity of $1.815 \mu \mathrm{S} / \mathrm{cm}$ at receiving point and 1.235 $\mu \mathrm{S} / \mathrm{cm}$ at outlet [14].

Kulkarni et al. (2016) performed a study on waste water quality and found $\mathrm{pH}$ of 6.2-6.9 at receiving point and $\mathrm{pH}$ of 7.1-7.5 at outlet, batch reactor mode process increased the $\mathrm{pH}$ value [15]. A study on sewage water management system was conducted by Ashok et al. (2018) for design of decentralized waste water treatment which stated $\mathrm{pH}$ of 6.5-8.5 at receiving point and 6.5-8.5 at outlet [16]. The research on water quality assessment of sewage treatment plant is conducted by Agayemang et al. (2013) which stated $\mathrm{pH}$ of 10.6-11.4 at receiving point and 7.7-8.7 at outlet. The $\mathrm{pH}$ decreased because of sulphuric acid used in the treatment process. Sahu and Negi (2015) conducted a study on performance evaluation of waste water treatment plant which recorded $\mathrm{pH}$ of 7.5 at receiving point and 7.1 at outlet [11]. Rajkumar (2016) performed a study on interpretation of biological method for the sewage treatment and found $\mathrm{pH}$ of 7.20 at receiving point and 7.5 at outlet [8].

Review based on variation in conductivity and $\mathrm{pH}$ in Sewage Treatment Plant

\begin{tabular}{|l|l|l|l|l|}
\hline \multirow{2}{*}{ Author } & \multicolumn{2}{|c|}{ Conductivity $(\mu \mathrm{S} / \mathrm{cm})$} & \multirow{2}{*}{ Remarks } & Ref. \\
\cline { 2 - 3 } & Inlet & Outlet & & \\
\hline
\end{tabular}




\begin{tabular}{|c|c|c|c|c|}
\hline Durga et al. (2013) & 987 & 1,080 & Higher algal abundance. & [12] \\
\hline $\begin{array}{l}\text { Agyemang et al. } \\
\text { (2013) }\end{array}$ & $1750 \pm 20$ & $840 \pm 48$ & $\begin{array}{l}\text { The sewage obtained after treatment records unsatisfactory } \\
\text { results. }\end{array}$ & [5] \\
\hline $\begin{array}{l}\text { Khushwah et al. } \\
\text { (2012) }\end{array}$ & 2.323 & 1.423 & $\begin{array}{l}32.37 \% \text { of reduction and sewage quality did not appear to } \\
\text { comply with electrical conductivity. }\end{array}$ & [13] \\
\hline $\begin{array}{l}\text { Khushwah et al. } \\
\text { (2011) }\end{array}$ & 1.815 & 1.235 & Defined domestic usage limits. & [14] \\
\hline \multirow{2}{*}{ Author } & \multicolumn{2}{|c|}{$\mathrm{pH}$} & \multirow{2}{*}{ Remarks } & \multirow{2}{*}{ Ref. } \\
\hline & Inlet & Outlet & & \\
\hline $\begin{array}{l}\text { Kulkarni et al. } \\
\text { (2016) }\end{array}$ & 6.2 to 6.9 & 7.1 to 7.5 & $\begin{array}{l}\text { pH value increased because of cyclic activated treatment } \\
\text { process. }\end{array}$ & [15] \\
\hline $\begin{array}{l}\text { Ashok et al. } \\
\text { (2018) }\end{array}$ & 6.5 to 8.5 & 6.5 to 8.5 & $\mathrm{pH}$ value remained constant & [16] \\
\hline $\begin{array}{l}\text { Agyemang et al. } \\
\text { (2013) }\end{array}$ & 10.6-11.4 & 7.9 to 8.9 & pH value decreased because of sulphuric acid & [5] \\
\hline $\begin{array}{l}\text { Sahu and Negi } \\
\text { (2015) }\end{array}$ & 7.50 & 7.10 & $\begin{array}{l}\mathrm{pH} \text { value decreased, water after treatment obtained at } \\
\text { outlet was found to be suitable for irrigation purposes. }\end{array}$ & {$[11]$} \\
\hline $\begin{array}{l}\text { Rajkumar } \\
(2016)\end{array}$ & 7.20 & 7.5 & Determined feasibility of particular sample. & [8] \\
\hline
\end{tabular}

\subsection{Chemical Oxygen Demand}

Dahamsheh and Wedyan (2017) performed a study on interpretation of performance of sewage treatment plant which recorded COD of 314.6-356.4 mg/l at receiving point and 50.2-55 mg/l at outlet [10]. Durga et al. (2013) performed the study on treatment efficiency of algae based waste water treatment plant which stated COD of $455.7 \mathrm{mg} / \mathrm{l}$ at receiving point and $206 \mathrm{mg} / \mathrm{l}$ at outlet [12]. Chen et al. (2018) performed a study on technology choice for municipal waste water treatment which recorded COD $250 \mathrm{mg} / \mathrm{l}$ at receiving point and 55mg/l at outlet [17]. Rajkumar (2016) performed a study on interpretation of biological method for the sewage treatment and found COD of $930 \mathrm{mg} / \mathrm{l}$ at receiving point and $55 \mathrm{mg} / \mathrm{l}$ at outlet [8]. Sahu and Negi (2015) conducted a study on performance evaluation of waste water treatment plant which recorded COD of $455.50 \mathrm{mg} / \mathrm{l}$ at receiving point and $25.58 \mathrm{mg} / \mathrm{l}$ at outlet [11]. The values of COD obtained from various papers is listed below in table.

Review based on variation in COD of Sewage Treatment Plant

\begin{tabular}{|l|c|c|l|c|}
\hline \multirow{2}{*}{ Author } & \multicolumn{2}{|c|}{ COD (mg/l) } & \multirow{2}{*}{ Remarks } & Ref. \\
\cline { 2 - 5 } & Inlet & Outlet & & {$[10]$} \\
\hline $\begin{array}{l}\text { Dahamsheh and } \\
\text { Wedyan (2017) }\end{array}$ & $314.6-356.4$ & $50.2-55.0$ & $83.3-85 \%$ reduction in COD. & {$[12]$} \\
\hline Durga et al. (2013) & 455.7 & 206.0 & $55 \%$ Removal. & \\
\hline
\end{tabular}




\begin{tabular}{|l|c|c|l|c|}
\hline Chen et al. (2018) & 250 & 55 & $82 \%$ Removal. & {$[17]$} \\
\hline Rajkumar (2016) & 930 & 55 & $\begin{array}{l}\text { Conventional aeration treatment decreased } \\
\text { COD value by 876. }\end{array}$ & {$[8]$} \\
\hline Sahu and Negi (2015) & 455.50 & 25.58 & $\begin{array}{l}\text { Recommend use in flushing purpose or } \\
\text { construction activities. }\end{array}$ & {$[11]$} \\
\hline
\end{tabular}

\subsection{Total Suspended Solids (TSS) and Total Dissolved Solids (TDS)}

Bhagwatkar et al. (2017) conducted a study of decentralized sewage treatment which stated TSS of $100-200 \mathrm{mg} / \mathrm{l}$ at receiving point and $<10 \mathrm{mg} / \mathrm{l}$ at outlet [6]. A study on water quality assessment of sewage treatment plant was conducted by Agyemang et al. (2013) which recorded TSS of $85 \pm 25 \mathrm{mg} / \mathrm{l}$ at receiving point and $175 \pm 110 \mathrm{mg} / \mathrm{l}$ at outlet [5]. Sahu and Negi (2015) conducted a study on performance evaluation of waste water treatment plant which stated TSS of $235 \mathrm{mg} / \mathrm{l}$ at receiving point and $13 \mathrm{mg} / \mathrm{l}$ at outlet [11]. Hangargekar and Takpere (2015) performed a case study on sewage treatment plant and common sewage treatment plant which recorded TSS of $240 \mathrm{mg} / \mathrm{l}$ at receiving point $80 \mathrm{mg} / \mathrm{l}$ at outlet [18]. Dahamsheh and Wedyan (2017) conducted a study on interpretation of performance of sewage treatment plant which resulted in TSS of $264 \mathrm{mg} / \mathrm{l}$ at receiving point and $46.1 \mathrm{mg} / \mathrm{l}$ at outlet [10]. Rajkumar (2016) performed a study on interpretation of biological method for the sewage treatment and found TSS of $755 \mathrm{mg} / \mathrm{l}$ at receiving point and $12 \mathrm{mg} / \mathrm{l}$ at outlet [8].

Hangargekar and Takpere (2015) performed a case study on sewage treatment plant and common sewage treatment plant which recorded TDS of $3300 \mathrm{mg} / \mathrm{l}$ at receiving point and 2500 $\mathrm{mg} / \mathrm{l}$ at outlet [18]. A study on assessment of sewage water treatment plant was conducted by Agayeamang et al. (2013) which results in TDS of $860 \pm 55 \mathrm{mg} / \mathrm{l}$ at receiving point and $830 \pm 58$ $\mathrm{mg} / \mathrm{l}$ at outlet [5]. Sahu and Negi (2015) conducted a study on performance evaluation of waste water treatment plant which recorded TDS of $498 \mathrm{mg} / \mathrm{l}$ at receiving point and $430 \mathrm{mg} / \mathrm{l}$ at outlet [11]. A study on interpretation of biological method for sewage treatment was conducted by Rajkumar (2016) which stated TDS of $1595 \mathrm{mg} / \mathrm{l}$ at receiving point and $1945 \mathrm{mg} / \mathrm{l}$ at outlet [8]. Durga et al. (2013) performed the study on treatment efficiency of algae based waste water treatment plant which resulted in TDS of $780 \mathrm{mg} / \mathrm{l}$ at receiving point and $850 \mathrm{mg} / \mathrm{l}$ at outlet [12]. The values of TSS and TDS obtained from various papers is listed in table below.

Review based on variation in TSS and TDS of STP plant

\begin{tabular}{|l|l|l|l|c|}
\hline \multirow{2}{*}{ Author } & \multicolumn{2}{|c|}{ TDS (mg/l) } & Remarks & Ref. \\
\cline { 2 - 5 } & Inlet & Outlet & Very small reduction observed in dissolved & [18] \\
\hline $\begin{array}{l}\text { Hangargekar and } \\
\text { Takpere (2015) }\end{array}$ & 3300 & 2500 & $\begin{array}{l}\text { Reliable with the EPA Ghana } \\
\text { Guideline for beverage industries discharging } \\
\text { into water bodies. }\end{array}$ & {$[5]$} \\
\hline Agyemang et al. (2013) & $860 \pm 55$ & $830 \pm 58$ & Microbial growth. & {$[12]$} \\
\hline Durga et al. (2013) & 780 & 850 & Recommend use in cooling towers. & {$[11]$} \\
\hline Sahu and Negi (2015) & 498 & 430 & & {$[8]$} \\
\hline Rajkumar (2016) & 1595 & 1945 & Reduced values using RO plant. & \\
\hline
\end{tabular}




\begin{tabular}{|c|c|c|c|c|}
\hline \multirow{2}{*}{ Author } & \multicolumn{2}{|c|}{ TSS (mg/l) } & \multirow{2}{*}{ Remarks } & \multirow{2}{*}{ Ref. } \\
\hline & Inlet & Outlet & & \\
\hline $\begin{array}{l}\text { Bhagwatkar et al. } \\
\text { (2017) }\end{array}$ & $100-200$ & $<10$ & $\begin{array}{l}\text { Load on intermediate sewage treatment units } \\
\text { decreased. }\end{array}$ & [10] \\
\hline $\begin{array}{l}\text { Hangargekar and } \\
\text { Takpere (2015) }\end{array}$ & 240 & 80 & Efficient reduction. & [18] \\
\hline Agyemang et al. (2013) & $85 \pm 25$ & $175 \pm 110$ & Partial sludge settlement & [5] \\
\hline Sahu and Negi (2015) & 235 & 13 & Chlorination is required before using this water. & [11] \\
\hline Rajkumar (2016) & 755 & 12 & Removal of the pollutants. & [8] \\
\hline $\begin{array}{l}\text { Dahamsheh and } \\
\text { Wedyan (2017) }\end{array}$ & 264 & 46.1 & 79- $85.6 \%$ decrease in TSS. & [10] \\
\hline
\end{tabular}

\subsection{Turbidity and Colour}

A study on sewage water management system was conducted by Ashok et al. (2018) for design of decentralized waste water treatment which stated turbidity of $122 \mathrm{mg} / \mathrm{l}$ at receiving point and $<0.1 \mathrm{mg} / \mathrm{l}$ at outlet [16]. The research on water quality assessment of sewage treatment plant was conducted by Agyemang et al. (2013) which recorded turbidity of $45.6 \pm 3.6 \mathrm{mg} / \mathrm{l}$ at receiving point and $92.6 \pm 65.4 \mathrm{mg} / \mathrm{l}$ at outlet [5]. Kesalkar et al. (2012) performed a study on physiochemical characteristics of sewage from paper industry and recorded 13 hazen units at receiving point and 18 hazen units at outlet which did not lie in the permissible limits [19]. Wang et al. (2013) performed a study on textile industry sewage for colour removal which stated 70 hazen units at receiving point and 140 hazen units at outlet [20]. The study on water quality assessment of sewage treatment plant was conducted by Agyemang et al. (2013) which obtained 75.8 \pm 35 hazen units at receiving point and $100 \pm 40$ hazen units at outlet [5]. Sivakumar (2014) performed a study on textile industry sewage for colour removal and recorded 30 hazen units at receiving point and 1.62 hazen units at outlet [21]. This might be due to application of constructed wetland using Lemna minute L. Uysal and Biligic (2017) conducted a study on colour removal from sewage by using aerobic filter reactors which recorded 425 hazen units at receiving point and 62 hazen units at outlet [22].

Review based on variation in Turbidity and Colour

\begin{tabular}{|c|c|c|c|c|}
\hline \multirow[t]{2}{*}{ Author } & \multicolumn{2}{|c|}{$\begin{array}{l}\text { Turbidity (mg/l) and Color } \\
\text { (Hazen) }\end{array}$} & \multirow[t]{2}{*}{ Remarks } & \multirow[t]{2}{*}{ Ref. } \\
\hline & Inlet & Outlet & & \\
\hline $\begin{array}{l}\text { Ashok et al. } \\
\text { (2018) }\end{array}$ & 122 & $<0.1$ & Complex technical solutions. & {$[16]$} \\
\hline Agyaemang et al. (2013) & $45.6 \pm 3.6$ & $92.4 \pm 65.6$ & Turbidity value lies in the range of $30-220$. & [5] \\
\hline $\begin{array}{l}\text { Kesalkar et al. } \\
\text { (2012) }\end{array}$ & 13 & 18 & $\begin{array}{l}\text { Do not lie in the permissible limits after } \\
\text { treatment. }\end{array}$ & [19] \\
\hline Agyemang et al. (2013) & $75.8 \pm 35$ & $100 \pm 40$ & $\begin{array}{l}92 \% \text { of removal in color, by } \\
\text { biodegradation of organic matter. }\end{array}$ & [5] \\
\hline
\end{tabular}




\begin{tabular}{|l|l|l|l|l|}
\hline Wang et al. (2007) & 70 & 140 & Color level is increased. & [20] \\
\hline Uysal and Bilgic (2017) & 425 & 62 & 30 to $54 \%$ color removal. & [22] \\
\hline Shivakumar (2014) & 30 & 1.62 & $94 \%$ color removal. & {$[21]$} \\
\hline
\end{tabular}

\subsection{Total Phosphorus}

Sahu and Negi (2015) conducted a study on performance interpretation of waste water treatment plant which recorded $1.50 \mathrm{mg} / \mathrm{l}$ of total phosphorus at receiving point and $1.20 \mathrm{mg} / \mathrm{l}$ at outlet [11]. Prachi et al. (2014) performed a study on performance interpretation of 25MLD waste water treatment plant and found $4.0 \mathrm{mg} / \mathrm{l}$ of total phosphorus at receiving point and 1.5 $\mathrm{mg} / \mathrm{l}$ at outlet [23]. A study was conducted by Vitez et al. (2012) for interpretation of efficiency of sewage treatment plant which stated $1.08 \mathrm{mb} / \mathrm{l}$ of total phosphorus at receiving point and $1.00 \mathrm{mg} / \mathrm{l}$ at outlet [24]. Shiilton et al. (2006) performed a study on phosphorus removal and found $8.5 \mathrm{mg} / \mathrm{l}$ of total phosphorus at receiving point and $8.8 \mathrm{mg} / \mathrm{l}$ at outlet [25]. The variation in values of total phosphorus is shown in table.

Review based on values of Total Phosphorus

\begin{tabular}{|l|l|l|l|l|}
\hline \multirow{2}{*}{ Author } & \multicolumn{2}{|c|}{$\begin{array}{c}\text { Total Phosphorus } \\
\text { (mg/l) }\end{array}$} & \multirow{2}{*}{ Remarks } & Ref. \\
\cline { 2 - 4 } & Inlet & Outlet & & 72.79\% of total phosphorus is removed. \\
\hline Prachii et al. (2014) & 4.0 & 1.5 & Treatment with Ultra Filters. & {$[23]$} \\
\hline $\begin{array}{l}\text { Sahu and Negi } \\
(2015)\end{array}$ & 1.50 & 1.20 & Reducing efficiency is about 7\%. & {$[11]$} \\
\hline Viteaz et al. (2012) & 1.08 & 1.00 & Reducing efficiency is about 70\%. & {$[24]$} \\
\hline Sheilton et al. (2006) & 8.5 & 8.8 & & {$[25]$} \\
\hline
\end{tabular}

\subsection{Microbial Count}

Xiuhua et al. (2014) conducted a study on different dose of disinfectant and recorded 70 microbial at receiving point and 2 at outlet [26]. Chabi and Acour (2014) performed a study on disinfection of drinking water constraints and found 0.05 microbial at receiving point and 0.0005 at outlet [27]. Also Hong and Chiing (2009) performed a study on design of MBR type waste water treatment plant, which records $1.24 \times 10^{7}$ microbial count at receiving point and no value got detected at outlet [28]. The variation of microbial count is shown in table below.

Review based on Microbial Count

\begin{tabular}{|c|c|c|c|c|}
\hline \multirow{2}{*}{ Author } & \multicolumn{2}{|c|}{ Microbial (MPN/100ml) } & \multirow{2}{*}{ Remarks } & \multirow{2}{*}{ Ref } \\
\hline & Inlet & Outlet & & \\
\hline $\begin{array}{l}\text { Hong and Chiing } \\
\text { (2009) }\end{array}$ & $1.24 \times 10^{7}$ & Not- Detected & $\begin{array}{l}\text { MBR technique found to be effective in almost } 100 \% \\
\text { removal of microbial. }\end{array}$ & [28] \\
\hline Chabi and Acour (2014) & 0.5 & 0.005 & $\begin{array}{l}99 \% \text { of the removal of microorganisms is due to the } \\
\text { application of chlorine. }\end{array}$ & [27] \\
\hline
\end{tabular}




\begin{tabular}{|l|l|l|l|l|}
\hline Xiehua et al. (2014) & 70 & 2.2 & $\begin{array}{l}\text { Found statistically significant in recovering microbial } \\
\text { count. }\end{array}$ & [26] \\
\hline
\end{tabular}

\section{Conclusion}

The paper focuses on reviewing the various sewage treatment methods and their results. An effort is put to comprehend how the concentrations of different parameters change with change in treatment method. After going through various papers it was found that final value of conductivity obtained at outlet do not match with the standard values. Sewage treatment plant when investigated for determining efficiency of treatment recorded moderate level of treatment with $90 \%$ removal of BOD. The results of both influent and effluent TDS were found to be consistent.

Sewage after treatment in STP can be used as an alternative to fresh water in gardening, flushing and many other activities. The level of treatment is based on the purpose which will help in deciding the technology to be used. If sewage is permitted to enter water bodies without any treatment, it will be hazardous. Hence it is recommended to treat before releasing into the ecosystem.

\section{References}

1. Tulip, D.R.E, "Study on various technologies in wastewater treatment", International Journal of Civil Engineering and Technology (IJCIET), 8(8), 2017, 1576-1580.

2. Pushpaltha, P. and Kalpana, P., "Design approach for sewage treatment plant: a case study of srikakulam greater municipality”, India. International Journal of Modelling and Simulation, 18(2), 1998, 112-116.

3. Soares, R.B., Memelli, M.S., Roque, R.P. and Gonçalves, R.F., "Comparative analysis of the energy consumption of different wastewater treatment plants”, International Journal of Architecture, Arts and Applications, 3(6), 2017, 79-86.

4. Agyemang, E.O., Awuah, E., Darkwah, L., Arthur, R. and Oseiv, G., "Water quality assessment of a wastewater treatment plant in a Ghanaian Beverage Industry", International Journal of Water Resources and Environmental Engineering, 5(5), 2013, 272- 279.

5. Bhagwatkar, A., Kamble, S., More, K. and Amup, A.K., "Decentralized wastewater treatment facility”, International journal of engineering sciences \& management, 3(4), 2017, 144-155.

6. Rajkumar, K., “An Evaluation of Biological Approach for the Effluent Treatment of Paper Boards Industry - An Economic Perspective”, Journal of Bioremediation \& Biodegradation 7(5), 2016,1-13

7. Patil, Y., Raut, Y., Patil, Y. and Dhurve, S., "Design of sewage treatment plant units for st.john college campus”, International Journal of Scientific Research Engineering \& Technology (IJSRET), 7(3), 2018, 177-181

8. Dahamsheh, A. and Wedyan, M., "Evaluation and assessment of performance of AlHussein bin Talal University (AHU) wastewater treatment plants”, International Journal of Advanced and Applied Sciences 4(1), 2017, 84-89. 
9. Negi, M.S. and Sahu, V., "Performance evaluation of 9 MLD sewage treatment plant at Gurgaon and cost effective measures in treatment process”, Civil Engineering and Urban Planning: An International Journal (CiVEJ), 2(3), 2015, 1-7.

10. Kushwah, R., Malik, S. and Singh, A., "Water Quality Assessment of Raw Sewage and Final Treated Water with Special Reference to Waste Water Treatment Plant Bhopal, MP, India”, Research Journal of Recent Science, 1, 2012, 185-190.

11. Kushwah, R., Bhajpai, A., Malik, S. and Singh, A., "Seasonal variation of physicochemical parameters of waste water from a sewage treatment plant, Bhopal (India)”, Int. J. Chem. Sci.: 9(3), 2011, 1545-1552.

12. Kulkarni, B., Wanjule, R.V., and Shinde, H.H., "Study on Sewage Quality from Sewage Treatment Plant at Vashi, Navi Mumbai”, Science Direct Materials Today, 5, 2016, 1859-1863.

13. Ashok, S.S., Kumar, T. and Bhalla, K., "Integrated Greywater Management Systems: A Design Proposal for Efficient and Decentralised Greywater Sewage Treatment”, 25th CIRP Life Cycle Engineering (LCE) Conference, Copenhagen, Denmark, Procedia CIRP 69, 2018, 609 - 614.

14. Chen, X., Xu, Z., Yao, L. and Ma, N., "Processing Technology Selection for Municipal Sewage Treatment Based on a Multi-Objective Decision Model under Uncertainty”, Int. J. Environ. Res, 15, 2018, 1-18.

15. Hangargekar, P.A. and Takpere, K.P., “A Case Study on Waste Water Treatment Plant, CETP (Common Effluent Treatment Plant)", International Journal of Innovative Research in Advanced Engineering (IJIRAE), 2, 2015, 34-39.

16. Kesalkar, V.P., Khedikar, I.P. and Sudame, A.M., "Physio-chemical characteristics of wastewater from Paper Industry”, International Journal of Engineering Research, 2(4), 2012, 137-143.

17. Wang, Y., Gao, B, Y., Yue, Q, Y., Wei, J.C., Zhou, W, Z. and Gu, R., “Color removal from textile industry wastewater using composite flocculants”, Environmental Technology, 28, 2007, 629-637.

18. Uysal, Y., Bilgic, M., “Color removal from wastewater by using two-step (biological and chemical) aerobic filter reactors”, Global NEST Journal, 20, 2017, 1-7.

19. Vítěz, T., Ševčíková, J. and Oppeltová, P., "Evaluation of the efficiency of selected wastewater treatment plant”, Acta univ. agric. silvic. Mendel. Brun, 1, 2012 173-180.

20. Shilton, A.N., Elmetri, I., Drizo, A., Pratt, S., Haverkamp, R.G. and Bilby, S.C., "Phosphorus removal by an active slag filter-a decade of full scale experience", Science direct, 40, 2006, 113-118.

21. Sharda, A.K., Sharma, M.P. and Sharwan K., "Performance Evaluation of Brewery Waste Water Treatment Plant”, International Journal of Engineering Practical Research. 2(3), 2013, 105-111.

22. Vrushali, S. and Kaustav, C., "Sewage treatment and reuse - a step towards water conservation”, International science journal, 1(2), 2014, 15-22.

23. Nagwekar, P.R., "Removal of Organic Matter from Wastewater by Activated Sludge Process - Review”, International Journal of Science, Engineering and Technology Research (IJSETR), 3(5), 2014, 1260-1263. 
24. Dighe, B.J., Dr. Patil, P.R. and Dr.Mishra, M., "Reduction of Ammonia and Turbidity in Wastewater of Pharmaceutical Industry”, International Journal of Science and Research (IJSR), 4(5), 2013, 2949-2954.

25. Wakode, P.N. and Sayyad, S.U., "Performance Evaluation of 25 MLD Sewage Treatment Plant (STP) at Kalyan”, American Journal of Engineering Research (AJER) e-ISSN: 2320-0847, 3(3), 2014, 310-316.

26. Li, X., Xu, C.J. and Zhao, S.J., "Experimental study on disinfection effect of different dose of rapid hand disinfectant”, International journal of nursing sciences, 1, 2014, 212-214.

27. Achour, S. and Chabbi, F., "Disinfection of drinking water-constraints and optimization perspectives in Algeria”, Larhyss Journal, 19, 2014, 193-212.

28. Ching, K.F. and Hong, N., "Design and Operation of MBR Type Sewage Treatment Plant at Lo Wu Correctional Institution, Hong Kong”, 2009, 1-9. 